\title{
ASSESSMENT OF CULTURAL, BIOCHEMICAL AND GENETIC CHARACTERISTICS OF FRANKIA ISOLATES, THEIR NODULATION AND SYMBIOTIC NITROGEN FIXATION WITH CASUARINA TREES \\ El-Kammah, M. A. ${ }^{1}$; T. M. El-Essawi'; M. A. Azzazy ${ }^{2}$ and S. I. Gadow ${ }^{2}$ \\ 1- Soil Science Dept., Fac. of Agric., Kafrelsheikh Univ., Kafr El-Sheikh, Egypt 2- Agric. Microbiology Dept., National Research Center, Dokki, Cairo, Egypt.
}

\begin{abstract}
The microsymbiont Frankia genus belongs to the order of filamentous bacteria, the actinomycetales, family Frankiaceae, is Gram-positive bacteria fixing atmospheric nitrogen which forms symbiotic association with actinorhizal Casuarina glauca. C. glauca is an important introduced tree species in Egypt, valued for windbreaks and shelterbelt; land stabilization and soil improvement.

The present study concerned with the phenotypic, ecological and genetic characters; symbiotic competence and host specificity of some local Frankia isolates with Casuarina trees.

** Sixteen native Frankia pure isolates were isolated from root nodules of Casuarina trees, collected from different ecological Egyptian soils and their characteristics assessed in comparison with foreign reference Frankia isolates.

** Frankia isolates were grown well in synthetic nutrient medium. Vegetative hyphae, vesicles; sporangia and reproductive torulose hyphae (RTH) were observed. According to their physiological properties and plasmids number it was found that the isolated Frankia were identified as fifteen different Frankia isolates belonging to Frankia Casuarina. The characterization of Frankia isolates at DNA level revealed that existence of a large diversity with the exception of two isolates that were completely identical in all parameters using RFLP analysis.

** Inoculation of Casuarina seedlings with the various local Frankia isolates induced nodulation (nodules number and dry weights) and enhanced their vegetative growth parameters (stem lengths, branches and shoots dry weight) over the foreign reference strain.

** Some environmental factors included resistance to different antibiotics, neutral salinity and various $\mathrm{C}$-sources utilization were investigated well in comparison with imported foreign reference strain.

** Performance symbiotic $\mathrm{N}_{2}$-fixation of various indigenous Frankia isolates were judged by the percent shoots and roots $\mathrm{N}$-content and $\mathrm{N}$-uptake (mg/seedling) of Casuarina seedlings cultivated in both calcareous and sandy soils. Efficacy of Casuarina seedlings to $\mathrm{N}_{2}$-fixation was significantly increased upon inoculation with the most local Frankia isolates, which resulted in augmentation of $\mathrm{N}$-content and uptake over the reference strain.

** Highly efficient, native indigenous Frankia isolated from Kafr El-Sheikh and those from Ismailia regions identified as salinity tolerant, characterized by well intrinsic antibiotics resistance, showed greatly response to different C-sources and displayed highly symbiotic competence and effectiveness on Casuarina glauca, which surpassed the imported foreign reference Frankia strain.

Therefore, such isolates were strongly recommended to be applied as inocula for Casuarina species grown in Egyptian soils.
\end{abstract}




\section{El-Kammah, M. A. et al.}

The obtained data clearly emphasize the importance of isolation of proper Frankia strains for high compatible, resistant processed inocula for Casuarina cultivated under ecological conditions similar to initial from which they were isolated i.e. initial niches.

Keywords: Frankia, Casuarina, isolation, nodulation, actinorhizal plants, antibiotics, plasmids, microsymbionts; and symbiotic $\mathrm{N}_{2}$-fixation.

\section{INTRODUCTION}

Efforts are made to increase and introduce $\mathrm{N}_{2}$-fixing trees to Egyptian agriculture practices. Also, the erosion control and sustaining the urban and rural conditions needs efficient soil stabilization which mainly can be achieved by forestation (Diem \& Dommergues 1990b). Therefore investigations are continued to provide informations on such trees concerning ecology, microbiology and inoculation with specific microsymbionts (endophytes).

The $\mathrm{N}_{2}$-fixing partnership between Frankia and actinorhizal nonleguminous woody shrubs and trees such as Casuarina is very important to agricultural and silviculture practices. This symbiosis have the potential to free the host plant from dependence on nitrogenous fertilizers as well as to increase soil fertility. The full realization of this potential depends on maximizing the contribution of each partner, catering to specificity in the association and providing conditions for plant growth and nodules formation. El-Lakany (1983a, b; 1985 and 1986) reported that nitrogen fixing trees with special reference to Casuarina are being plants on a wide scale in tropics to provide fuel wood construction materials, fodder and nitrogen-rich biomass for improving soil fertility. The use of $\mathrm{N}_{2}$-fixing trees in agroforestry systems is receiving considerable attention as a source of nitrogen and much needed organic matter. Furthermore, these trees are used in the rehabilitation of damaged soils and in the protection of these soils against erosion. Casuarinaceae is the most important non-leguminous, dicotyledonous actinorhizal plants from the economical and ecological points of views including 96 species of woody trees and shrubs (Johnson \& Wilson, 1989), their roots are nodulated by a nitrogen-fixing actinomycetes of genus Frankia (Mariana et al., 2003).

Casuarina trees are the most planted in Egypt under different ecological conditions. El-Lakany (1986) Egypt is one of the poorest countries in natural forests in the world. Most of these species symbiotically fix nitrogen with Frankia which was recently isolated from Comptonia peregrina by Callaham et al. (1978) and from nodules of Casuarina equisetifolia by Diem \& Dommergues (1983). First report on isolation and culture of effective Frankia strains in Egypt was by Girgis et al. (1990). The first trial to isolate Frankia directly from soil was achieved by Baker \& O'Keefe (1984) using sucrosedensity fractionation method. The microsymbiont Frankia genus belongs to the order of flilamentous bacteria, the actinomycetales, family Frankiaceae. The species concept in Frankia was based on host specificity and ultra structure of endophytes (Becking, 1981). Recent developments in Frankia 
classification and diversity are reviewed elsewhere (Benson \& Silvester, 1993 and Mullin \& Dobritsa, 1996).

Recently, Casuarina trees have proved to increasing annually the soil- $\mathrm{N}$ content by their biological $\mathrm{N}_{2}$-fixation ability around their rhizosphere in higher rates comparable to those of legumes-Rhizobium symbiosis (Long, 1996 and Franche et al., 1998).

In Egypt, a $\mathrm{N}_{2}$-fixing potential of $288 \mathrm{~kg} \mathrm{~N} / \mathrm{ha} /$ year has been reported for Casuarina (Gauthier et al., 1984). In addition, different actinorhizal species have the ability to grow well under a rang of environmental stresses such as high salinity, heavy metal, extreme $\mathrm{pH}$ (Dawson, 1990).

The basic knowledge of the symbiotic association between Frankia and actinorhizal plants still poorly understood, although it offers striking differences with the Rhizobium-legume symbiosis (Pawlowski \& Bisseling, 1996; Long, 1996 and Franche et al., 1998).

Also, little is known about the two partners and the ecological, genetical conditions affecting the cultural and symbiotic characteristics of local isolates of Frankia compared with a foreign reference strains.

The present study concerned with the morphological; cultural and ecological characteristics of native, local and high effective pure isolates of Frankia obtained from Casuarina root nodules cultivated in different ecological locations of Egyptian soils. Symbiotic performance of isolated cultures of Frankia were assessed i.e. assessment their efficiency in renodulating capacity, growth and symbiotic $\mathrm{N}_{2}$-fixation ability of Casuarina glauca seedlings under green house conditions.

In addition, the isolates were studied for their intrinsic antibiotic resistance (IAR); salt tolerance as well as carbon source utilization. The genetic diversity of isolated Frankia was determined using the restriction fragment length polymorphism (RFLP) of their DAN.

\section{MATERIALS AND METHODS}

\section{Collection of Casuarina nodules:}

Casuarina nodules were collected from different ecological locations of Egypt i.e. Ismailia; Kafr El-Sheikh and the New Valley Governorates (Table 1). The nodules were sampled with small parts of roots at the depth of 10-30 $\mathrm{cm}$ from soils surface. The viable nodules that had light brown color were selected, separated and transferred under controlled conditions.

Table (1): Locations and depths of Casuarina nodules samples and soil types.

\begin{tabular}{|c|c|c|c|c|}
\hline Locations & Soil types & Host trees & $\begin{array}{c}\text { Root nodules } \\
\text { depth (cm) }\end{array}$ & $\begin{array}{c}\text { Nodules } \\
\text { diameter } \\
\text { (cm) }\end{array}$ \\
\hline $\begin{array}{c}\text { Kafr El-Sheikh Fac. of Agric. } \\
\text { Farm Kafr El-Sheikh Univ. }\end{array}$ & Clay loam & C. cuinninghamiana & 20 & $3-5$ \\
\hline New Valley. Mout city & Clay loam & C. glauca & 36 & $2-4$ \\
\hline $\begin{array}{c}\text { Ismailia.Ismailai-Suez road } \\
(10 \mathrm{~km}) \text { apart }\end{array}$ & $\begin{array}{c}\text { Sandy clay } \\
\text { loam }\end{array}$ & C. glauca & 15 & $3-4$ \\
\hline
\end{tabular}




\section{El-Kammah, M. A. et al.}

\section{Characterizations of the studied soils:}

Representative composite arable soil samples were collected from Ismailia, Kafr El-Sheikh and the New Valley, from which Casuarina nodules were collected. Another soil samples of virgin calcareous and sandy soils, represent the new reclaimed soils, were collected also from Mariout Research Station and El-Nobaria city for the greenhouse experiments. The two groups of the soil samples were air dried, ground to pass through $2 \mathrm{~mm}$ sieve and kept for analyses at room temp.

The selected soil properties and total- $\mathrm{N}$ of roots and shoots of Casuarina glauca seedlings were determined using classical methods which reported by (Page et al., 1982; Klute, 1986; Carter, 1993 and Burt, 2004). studied soils.

Table (2) represent some physico-chemical characteristics of the

Table (2): Main analytical properties of the tested soils from different ecological regions..

\begin{tabular}{|c|c|c|c|c|c|c|c|c|c|c|c|c|c|c|c|c|}
\hline \multirow[b]{3}{*}{ Soils } & \multicolumn{4}{|c|}{$\begin{array}{l}\text { Particle size } \\
\text { distribution }\end{array}$} & \multirow{3}{*}{$\begin{array}{c}\text { Water } \\
\text { holding } \\
\text { capacity } \\
\text { WHC } \\
(\%)\end{array}$} & \multicolumn{11}{|c|}{ Chemical analysis } \\
\hline & \multirow{2}{*}{ 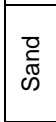 } & \multirow{2}{*}{$\overrightarrow{\bar{c}}$} & \multirow{2}{*}{$\frac{\vec{\sigma}}{U}$} & \multirow{2}{*}{$\begin{array}{l}\text { Texture } \\
\text { class }\end{array}$} & & \multirow{2}{*}{$\begin{array}{c}\mathrm{pH} \\
2.5: 1\end{array}$} & \multirow{2}{*}{$\begin{array}{c}\mathrm{EC} \\
\mathrm{dS} / \mathrm{m}\end{array}$} & \multirow{2}{*}{$\begin{array}{c}\mathrm{CaCO}_{3} \\
\%\end{array}$} & \multicolumn{4}{|c|}{$\begin{array}{c}\text { Soluble cations } \\
\text { meq/L }\end{array}$} & \multicolumn{3}{|c|}{$\begin{array}{c}\text { Soluble anions } \\
\mathrm{meg} / \mathrm{L}\end{array}$} & \multirow[b]{2}{*}{ O.M.\% } \\
\hline & & & & & & & & & $\mathrm{Ca}^{++}$ & $\mathrm{Mg}^{++}$ & $\mathrm{Na}^{+}$ & $\mathrm{K}^{+}$ & \multirow{2}{*}{$\begin{array}{c}\mathrm{CO}_{3}= \\
+ \\
\mathrm{HCO}_{3}\end{array}$} & $\mathrm{Cl}^{-}$ & $\mathrm{SO}_{4}=$ & \\
\hline \multicolumn{16}{|c|}{ Soils of collected nodules } & \\
\hline Kafr El-Sheikh & 8.9 & 32.8 & 58.3 & $\begin{array}{l}\text { Clay } \\
\text { loam }\end{array}$ & 50 & 8.2 & 12.9 & 2.9 & 32.8 & 26.4 & 67.3 & 2.5 & 3.5 & 85.0 & 40.5 & 1.98 \\
\hline New Valley & 27.9 & 36.4 & 35.7 & $\begin{array}{l}\text { Clay } \\
\text { loam }\end{array}$ & 40 & 7.9 & 0.9 & 3.5 & 3.0 & 1.8 & 3.9 & 0.3 & 0.2 & 5.5 & 3.3 & 1.13 \\
\hline Ismailia & 29.5 & 25.7 & 44.8 & $\begin{array}{l}\text { Sandy } \\
\text { clay } \\
\text { loam }\end{array}$ & 33 & 7.8 & 10.6 & 2.9 & 25.5 & 18.6 & 57.4 & 4.5 & 2.3 & 66.6 & 37.1 & 1.36 \\
\hline \multicolumn{17}{|c|}{ Soils of green house experiments } \\
\hline $\begin{array}{c}\text { Mariout } \\
\text { Research } \\
\text { Station (MRC) }\end{array}$ & 5.3 & 30.7 & 64 & $\begin{array}{l}\text { Clay } \\
\text { loam }\end{array}$ & 40 & 8.3 & 0.51 & 30.2 & 1.4 & 1.0 & 2.2 & 0.5 & 0.1 & 3.1 & 1.9 & 0.79 \\
\hline El-Nobaria city & 92.5 & 5 & 2.5 & Sandy & 26 & 7.7 & 1.7 & 1.4 & 4.8 & 3.1 & \begin{tabular}{|l|}
8.7 \\
\end{tabular} & 0.4 & 0.3 & 11.3 & \begin{tabular}{|l|l|}
5.4 \\
\end{tabular} & 0.51 \\
\hline
\end{tabular}

\section{Microbiological analyses of the tested soils:}

Pour-plate method was employed using the technique described by Louw \& Webley (1959). The serial dilution pipette method was used for the microbial counts on different selective media as following as listed in Table (3). Total microbial counts on nutrient agar medium (Difco, 1976). Total fungi counts on Martin's medium (Allen, 1953). Total actinomycetes counts on yeast extract-malt extract agar (Szabo 1974). Spore-formers counted on nutrient agar medium (Difco, 1976) after heating the dilution tubes for 10 minutes at $80-90^{\circ} \mathrm{C}$. Total $\mathrm{N}_{2}$-fixing microorganisms counts on combined carbon medium (Rennie, 1981). 
Table (3): The microbiological analyses of the tested soils from which nodules were collected and of soils which used in the green house experiments.

\begin{tabular}{|c|c|c|c|c|c|}
\hline $\begin{array}{r}\text { Microorganism } \\
\text { groups }\end{array}$ & $\begin{array}{c}\text { Total } \\
\text { microbial } \\
\text { counts }\end{array}$ & $\begin{array}{c}\text { Total fungal } \\
\text { counts }\end{array}$ & $\begin{array}{c}\text { Total } \\
\text { Actinomycet } \\
\text { es counts }\end{array}$ & $\begin{array}{c}\text { Total } \mathbf{N}_{2} \text { - } \\
\text { fixing } \\
\text { microorganis } \\
\text { ms counts }\end{array}$ & $\begin{array}{c}\text { Spore- } \\
\text { forming } \\
\text { Bacilli }\end{array}$ \\
\hline \multicolumn{6}{|c|}{ CFU units/g soil } \\
\hline \multicolumn{6}{|c|}{ Locations of collected nodules } \\
\hline Kafr El-Sheikh & $6.0 \times 10^{7}$ & $6.4 \times 10^{4}$ & $2.2 \times 10^{6}$ & $1.3 \times 10^{6}$ & $1.3 \times 10^{6}$ \\
\hline New Valley & $4.8 \times 10^{6}$ & $4.6 \times 10^{4}$ & $1.7 \times 10^{5}$ & $1.0 \times 10^{6}$ & $1.4 \times 10^{6}$ \\
\hline Ismailia & $11 \times 10^{7}$ & $4.5 \times 10^{4}$ & $2.1 \times 10^{5}$ & $2.1 \times 10^{6}$ & $1.2 \times 10^{5}$ \\
\hline Sariout Research & $1.0 \times 10^{7}$ & $6.1 \times 10^{4}$ & $2.7 \times 10^{5}$ & $1.3 \times 10^{5}$ & $1.7 \times 10^{4}$ \\
\hline Station (MRC) & $3.4 \times 10^{6}$ & $2.7 \times 10^{4}$ & $1.1 \times 10^{5}$ & $5.3 \times 10^{5}$ & $1.6 \times 10^{5}$ \\
\hline
\end{tabular}

Isolation of Frankia:

A number of selected fresh active nodules belonging to various locations were used to isolate different typical phenotypic Frankia isolates from the developed colonies on slants of Frankia medium according to the method of Benson (1982). The modified BAP liquid medium (Fontaine et al., 1986) was used for inocula preparation.

Reference strain and probes:

A Frankia foreign reference strain (Br) (ORS 020608) isolated from Casuarina equisetifolia grown in Brazil was kindly obtained from the Department of Plant Ecology, Faculty of Science. Chile (Muller et al., 1991). Source and germination bioassay of Casuarina seeds:

Seeds of Casuarina glauca were kindly obtained from Desert Development Center (DDC) of American University in Cairo, Egypt.

The seeds were surface sterilized by the immersing for 2 minutes in concentrated $\left(\mathrm{H}_{2} \mathrm{SO}_{4}\right)$, then washed with sterile tap water until the wash reached $\mathrm{pH} 7$ according to the method which reported by Selim \& Schwencke (1995).

The prepared seeds were germinated in sterile growth medium composed of washed sand and peatmoss (1:1) per volume for two weeks under room temperature.

Intrinsic antibiotic resistance (IAR) of isolated Frankia:

Antibiotics sensitivity of Frankia isolates were carried out by determining the growth inhibition plate assay according to Louis et al. (1999) using the following ten different types of antibiotics, rifampicin; kanmamycin; chloramphenicol; spectinomycin; tetracycline; ampiciline; erythromycin; neomycin sulfate; streptomycin sulfate and vancomycin hydrochloride. Different concentrations from each antibiotic, 15,30 and $60 \mu \mathrm{g} \mathrm{ml}^{-1}$ medium were used. Sterile Petri dishes were inoculated with $0.1 \mathrm{ml}$ of 10 days-old of the respective cultures. Qmod melted agar medium (Lalonde \& Calvert, 1979) flaks were supplemented with the respective antibiotics concentrations, then poured into the inoculated Petri dishes and incubated at $28 \pm 2^{\circ} \mathrm{C}$. The 
developed colonies on various antibiotic concentrations were recorded after 7 days of inoculation.

\section{Response of Frankia isolates to different C-sources:}

Five carbon sources i.e. sodium pyruvate; sodium acetate; glucose; sucrose and mannitol were tested as substitutions to sodium propionate that is considered the recommended carbon source for Frankia growth. BAP medium (Fontaine et al., 1986), without carbon source was autoclaved at $121^{\circ} \mathrm{C}$ for 15 minutes, while the various tested carbon sources were sterilized separately by filtration through sterile membrane filter of $0.45 \mu \mathrm{m}$ pore size supplemented to sterile Büchner set. After sterilization both BAP medium and various tested carbon were mixed together to give the required concentration $(0.2 \mathrm{~g}$ carbon/L). Conical flasks of $250 \mathrm{ml}$ volume containing $100 \mathrm{ml}$ of BAP medium including the respective carbon source were prepared and each was inoculated with homogenized $0.1 \mathrm{ml}$ of a freshly prepared Frankia isolate (10 days-old) as well as the reference strain. After incubation at $28 \pm 2^{\circ} \mathrm{C}$ for 10 days on a reciprocal shaker, each culture was counted using the serial dilution method.

\section{Tolerance of Frankia isolates to salinity:}

The tolerance of isolated and reference Frankia to different $\mathrm{NaCl}$ concentrations was studied by the growth inhibition plate. A stock solution of sodium chloride (40\%) and Qmod liquid medium (Lalonde \& Calvert, 1979) were prepared and autoclaved separately. After sterilization, the medium flasks were supplemented with aliquots of $\mathrm{NaCl}$ solution to give the final $\mathrm{NaCl}$ concentrations: control, 2.0; 4.0; 6.0; 6.5, 7.0, 7.5, 8.0, 8.5, 9.0, 10 and $10.5 \%$, and inoculated with $0.1 \mathrm{ml}$ of freshly prepared (10 days-old) homogenized liquid cultures of the tested Frankia isolates. After 10 days inoculation period at $28 \pm 2^{\circ} \mathrm{C}$ in a reciprocal shaker, each culture was counted on solid Qmode medium, containing the same previously mentioned $\mathrm{NaCl}$ concentrations, using the serial dilutions plate count.

\section{DNA and plasmid isolation of Frankia isolates:}

Plasmid numbers, sizes as well as DAN isolation and analyses of Frankia isolates were determined using the miniscreen method described by Rodriguez \& Tait (1983).

\section{Nodulation assay:}

Local Frankia isolates and the foreign reference $(\mathrm{Br})$ strain were tested for potential infectiveness and nodulation of host plant Casuarina glauca plant seedlings in a pot experiments under green house conditions of National Research Centre (NRC). Sterile plastic pots of $15 \mathrm{~cm}$ diameter were packed with $350 \mathrm{~g}$ sterile mixture of washed sand and peatmoss (1: 1) per volume. The growth medium was autoclaved at $121^{\circ} \mathrm{C}$ for 2 hours for three successive days.

The content of each pot was moistened with $500 \mathrm{ml}$ sterile $\mathrm{N}$-free Evan's nutrient solution (Evans et al., 1972), then mixed with $25 \mathrm{ml} 10$ days old culture of the respective Frankia isolate.

Sterilized seeds of Casuarina glauca were sown in pots, then covered with a thin layer of the same sterile growth medium. The pots were frequently irrigated with $\mathrm{N}$-free Evan's nutrient solution. After four months, the 
seedlings were uprooted, their roots were washed and the formed nodules were collected, counted, weighted and dried at $70^{\circ} \mathrm{C}$ for 48 hours for each seedlings. These fresh seedlings were subjected to estimate their vegetative growth parameters.

\section{$\mathrm{N}_{2}$-fixation assay:}

Isolated Frankia and reference $(\mathrm{Br})$ strain were tested for their efficiency to fix symbiotically the atmospheric nitrogen.

The virgin calcareous and sandy soils were sterilized and packed in sterile plastic pots (3 kg/pot) under green-house conditions of NRC. Pregerminated seeds of Casuarina glauca were transplanted (3 seedlings/pot), inoculated with $25 \mathrm{ml}$ of 10 days-old culture of the respective. Frankia isolates and covered with a thin layer of the same sterile soil. Irrigation was done with $\mathrm{N}$-free Evan's nutrient solution at intervals according plant needs (Huss-Danell, 1990) continuously for 10 months. At the end, shoots and roots $\mathrm{N}$-content $\%$ and plant $\mathrm{N}$-uptake (mg/seedling) were estimated.

\section{RESULTS AND DISCUSSION}

\section{Isolation; purification and phenotypic characteristics of isolated Frankia:}

The selected active nodules, which were collected from different locations represent different ecological sites of Egypt, were used for isolation and identification of different local isolates of Frankia using the microdissection method. Sterilized crushed nodule exudates was cultured on Frankia medium (Benson, 1982), containing sodium pyruvate as sole source of carbon and incubated at $28 \pm 2^{\circ} \mathrm{C}$ for one month.

Sixteen local isolates of Frankia were selected and subjected to more morphological studies using scanning electron microscopy SEM (10000x) for two isolates (Figs. 1 and 2).

Frankia differentiate into three cell type: Vegetative hyphae, sporangia and vesicles. These different cell types can be produced in pure culture, in plant and presumably in soils (Huss-Danell, 1990).

Fig (1) illustrates that the hyphae and vesicles of Frankia isolates were similar harmony of those findings by Lalonde et al. (1981) and Fontaine et al. (1984) who stated that Frankia sp. strain HFPAr 13 induced different formation of specialized structures, called vesicles, which are the proposed site of $\mathrm{N}_{2}$-fixation (localization of nitrogenase), Meesters et al. (1985) and Schultz \& Benson (1989).

Fig. (2) shows the specific fourth structure of Frankia that called reproductive torulose hyphase (RTH). Diem \& Dommergues (1984 and 1990a) found that some Frankia strains (ORS 021001) isolated from Casuarina junghuhniana produced a fourth structure results from conversion of a vegetative hypha into a wide torulose hypha with a thick double-layerd wall. These hyphae may be disrupted into spore-like cells and serve as the surviving and regenerating structure in Frankia strains from Casuarina when all vegetative hyphae are lysed. 


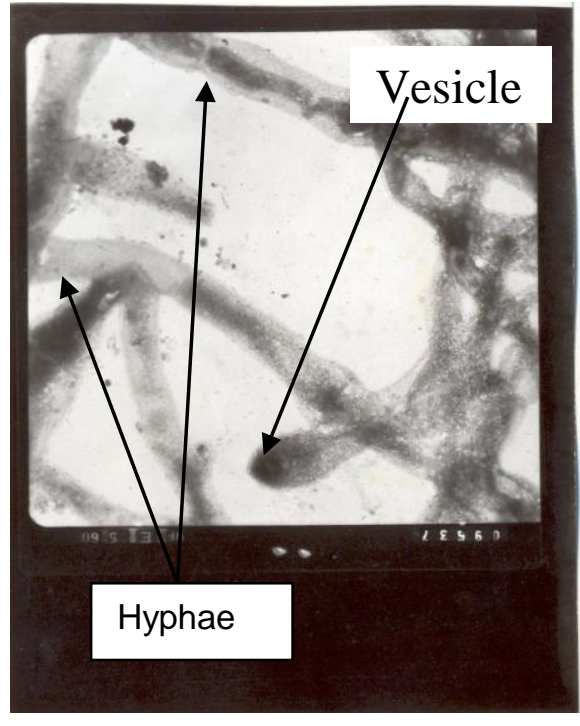

Fig (1): SEM of hyphae and vesicles

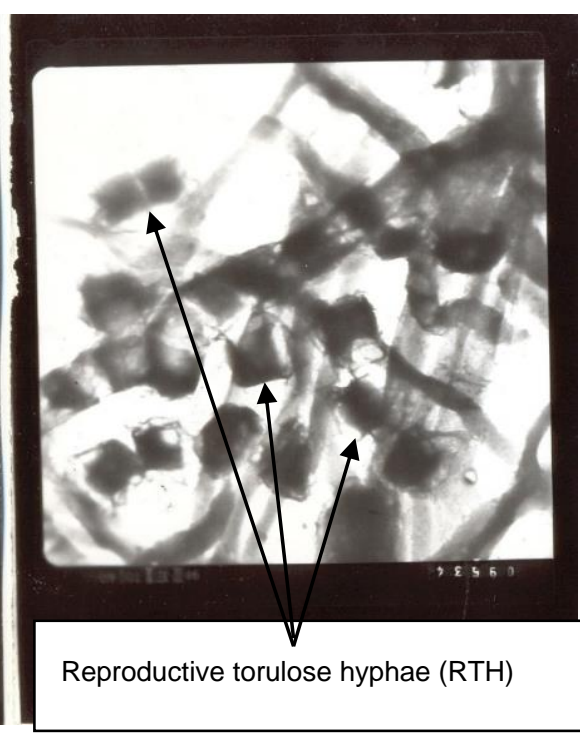

Fig (2): SEM of RTH

During growing the selected local Frankia isolates in the BAP liquid medium, New Valley isolates N01; N03; N04 and N05 as well as IO1 were produced colored pigments ranged from yellow to pink. The general morphological cultural characteristics of the different local Frankia isolates grown in BAP liquid medium as follows: Frankia isolates of Kafr El-Sheikh $\mathrm{K} 01 ; \mathrm{K} 02$ and $\mathrm{K} 03$ were formed clusters, without producing colored pigments in the BAP medium.

These clusters collected together and precipitated at the bottom formed white lumps with diameter of colony ranged between $1.2-2 \mathrm{~mm}$. Meanwhile, the other isolates were weakly grown only on the bottom $\mathrm{KO}_{4}$ and dispersed in the whole liquid $\mathrm{K}_{5}$.

Isolates of New Valley were relatively slow grown; forming colonies (diameter 1-2 $\mathrm{mm}$ ); producing soluble colored pigments in the BAP liquid medium with the exception of isolate N02. The isolate N01 formed small colonies firmly stickled on the wall and produced soluble red pigment in the medium. Isolates N02 and N03 were faster grown, formed larger colonies and clusters precipitated on the bottom, but isolate N03 secreted yellow soluble pigment.

The isolate N04 formed large colonies without producing clusters and secreted red pigment in the medium. Isolate N05 formed small colonies firmly attached to the wall, grew on the surface of growth liquid medium with grey color.

Frankia isolated from Ismailia displayed the lowest growth on the BAP medium, formed small colonies (diameter 1-2.5 mm) without forming soluble colored pigments in the medium, with the exception of isolate 101 . The isolate 101 formed small colonies and clusters precipitated as granules 
with pink pigment. Isolate 102 gave weak growth on the wall, formed clusters, deposited on the bottom. Isolate 103 showed weak gray growth dispersed in the liquid medium without forming film on the inner walls. Isolate 104 showed very weak growth on the inner walls without precipitated on the bottom. 105 showed heavy white growth on the surface forming pellicle without forming clusters or precipitates. 106 had a medium growth on the surface with grey colored mycelium.

The imported reference foreign Frankia strain $\mathrm{Br}$ was characterized by weak growth with small colonies $1-1.5 \mathrm{~mm}$ in diameter and formed clusters on the bottom. On solid medium it formed gray mycelium.

\section{Effect of some ecological conditions on growth of isolated Frankia:}

1. Intrinsic antibiotic resistance (IAR):

Antibiotic sensitivity of Frankia isolates have been used to differentiate and facilitate the identification of these isolates. Table (4) showed that the sixteen local isolates and the foreign reference $(\mathrm{Br})$ strain differed markedly in their resistance towards the tested (10) antibiotics.

The tested Frankia isolates, either locally isolated from the studied soils or the foreign reference strain $(\mathrm{Br})$ were incapable to grow at any of the tested concentration levels $\left(15,30\right.$ and $\left.60 \mu \mathrm{g} \mathrm{ml}^{-1}\right)$ of kanamycin, tetracycline and neomycin sulfate antibiotics.

Frankia isolates N01, N02 and N03 failed to grow on any of the tested antibiotic at any concentrations. From Table (4) it was observed that just one Frankia isolate N04 was able to grow on the concentration levels of vancomycin hydrochloride, but all the remainder isolates completely failed to grow on any of the tested concentrations.

Indigenous Frankia isolates of Kafr El-Sheikh and Ismailia showed the greatest capability to grow on various concentration levels of the most different tested antibiotics. However, local Frankia isolates of the New Valley displayed the lowest one in the exception of isolate N04, which was the most efficient isolate.

These observations could be ascribed to the adaptation of the isolates to their locations from which they were isolated as given in Tables ( 3 and 4).

Foreign reference $(\mathrm{Br})$ strain was more sensitive to all tested antibiotics at the three concentration levels and displayed the absolutely lowest resistance in the exception of erythromycin.

These results are in agreement with the findings of Carrasco et al. (1995) and Louis et al. (1999). They found that all the strains demonstrated sensitivity to some antibiotics. 
El-Kammah, M. A. et al.

Table (4): Resistance of Frankia isolates to certain concentrations of examined antibiotics.

\begin{tabular}{|c|c|c|c|c|c|c|c|c|c|c|c|c|c|c|c|c|c|c|}
\hline \multirow{2}{*}{ Antibiotic } & \multirow{2}{*}{$\begin{array}{c}\text { Conc. } \\
(\mu \mathrm{g} / \mathrm{ml})\end{array}$} & \multicolumn{17}{|c|}{ Frankia isolates } \\
\hline & & $\mathrm{Br}$ & K01 & K02 & K03 & K04 & K05 & N01 & N02 & N03 & N04 & N05 & 101 & 102 & 103 & 104 & 105 & 106 \\
\hline \multirow{3}{*}{ Rifampicin } & 15 & - & -1 & -1 & - & - & -1 & - & - & - & + & - & - & + & + & - & - & - \\
\hline & 30 & - & - & - & - & - & - & - & - & - & + & - & - & + & + & - & - & - \\
\hline & 60 & - & - & - & - & - & - & - & - & - & - & - & - & - & - & - & - & - \\
\hline \multirow{3}{*}{ Kanamycin } & 15 & - & - & - & - & - & - & - & - & - & - & - & - & - & - & - & - & - \\
\hline & 30 & - & - & - & - & - & - & - & - & - & - & - & - & - & - & - & - & - \\
\hline & 60 & - & - & - & - & - & - & - & - & - & - & - & - & - & - & - & - & - \\
\hline \multirow{3}{*}{ Chloramphenicol } & 15 & - & + & + & - & + & + & - & - & - & + & + & + & - & + & - & - & - \\
\hline & 30 & - & + & + & - & + & + & - & - & - & + & + & + & - & - & - & - & - \\
\hline & 60 & - & + & + & - & - & + & - & - & - & + & - & + & - & - & - & - & - \\
\hline \multirow{3}{*}{ Spectinomycin } & 15 & + & + & + & + & + & + & - & - & - & + & + & + & + & + & - & + & + \\
\hline & 30 & - & + & + & + & + & + & - & - & - & + & + & - & + & + & - & + & - \\
\hline & 60 & - & - & + & + & + & + & - & - & - & + & + & - & - & + & - & + & - \\
\hline \multirow{3}{*}{ Tetracycline } & 15 & - & - & - & - & - & - & - & - & - & - & - & - & - & - & - & - & - \\
\hline & 30 & - & - & - & - & - & - & - & - & - & - & - & - & - & - & - & - & - \\
\hline & 60 & - & - & - & - & - & - & - & - & - & - & - & - & - & - & - & - & - \\
\hline \multirow{3}{*}{ Ampicilline } & 15 & + & + & + & + & + & + & - & - & - & - & + & + & + & + & + & + & + \\
\hline & 30 & + & + & - & + & + & + & - & - & - & - & + & - & + & + & - & + & - \\
\hline & 60 & - & - & - & + & - & - & - & - & - & - & - & - & - & - & - & + & - \\
\hline \multirow{3}{*}{ Erythromycin } & 15 & + & + & + & + & + & + & - & - & - & + & + & + & + & + & - & + & + \\
\hline & 30 & + & + & + & + & + & + & - & - & - & + & + & + & + & + & - & + & - \\
\hline & 60 & + & + & + & - & + & + & - & - & - & + & + & + & - & + & - & + & - \\
\hline \multirow{3}{*}{$\begin{array}{l}\text { Neomycin } \\
\text { sulfate }\end{array}$} & 15 & - & - & - & - & - & - & - & - & - & - & - & - & - & - & - & - & - \\
\hline & 30 & - & - & - & - & - & - & - & - & - & - & - & - & - & - & - & - & - \\
\hline & 60 & - & - & - & - & - & - & - & - & - & - & - & - & - & - & - & - & - \\
\hline \multirow{3}{*}{$\begin{array}{l}\text { Streptomycin } \\
\text { sulfate }\end{array}$} & 15 & - & + & + & - & - & + & - & - & - & - & - & - & - & - & - & - & - \\
\hline & 30 & - & + & + & - & - & + & - & - & - & - & - & - & - & - & - & - & - \\
\hline & 60 & - & - & - & - & - & - & - & - & - & - & - & - & - & - & - & - & - \\
\hline \multirow{3}{*}{$\begin{array}{l}\text { Vancomycin } \\
\text { hydrochloride }\end{array}$} & 15 & - & - & - & - & - & - & - & - & - & + & - & - & - & - & - & - & - \\
\hline & 30 & - & - & - & - & - & - & - & - & - & + & - & - & - & - & - & - & - \\
\hline & 60 & - & - & - & - & - & - & - & - & - & + & - & - & - & - & - & - & - \\
\hline
\end{tabular}

Notes: + Means growth, - means no growth.

$\mathrm{Br}$ : : The reference strain

K01-K05 : Frankia isolates of Kafr El-Sheikh

N01-N05 : Frankia isolates of New Valley

I01-I06 : Frankia isolates of Ismailia

\section{Screening of the local and reference Frankia isolates under $\mathrm{NaCl}-$} Salinity stresses:

Neutral salinity stress was used for differentiating between the tested Frankia isolates. Tolerance of the indigenous, native Frankia isolates and the foreign reference strain, referred to as their growth of Frankia colony counts (CFU/ml) were assessed using Qmod liquid medium contained different $\mathrm{NaCl}$ concentration levels ranged from $2 \%$ to $10.5 \%$. Data illustrated in Fig. (3) revealed that the Frankia isolates and the foreign strain exhibited great differences in their $\mathrm{NaCl}$-stresses tolerance. Local Frankia isolates of $\mathrm{New}$ Valley region failed to grow above $4 \% \mathrm{NaCl}$, which showed the highest sensitivity to salinity stresses. The growth of the foreign reference Frankia strain was absent above $9 \% \mathrm{NaCl}$. 
Kafr El-Sheikh Frankia isolates showed the greatest resistance against $\mathrm{NaCl}$-salinity levels. These isolates were able to grow up to $9.5 \%$ with the exception of K04. Isolates $\mathrm{K} 03$ and $\mathrm{K} 05$ were the most tolerant Frankia to salinity stresses, since they were able to grow up to $10 \% \mathrm{NaCl}$.

Further, Ismailia Frankia isolates came second in salt tolerance. They tolerated $\mathrm{NaCl}$ concentration levels up to $7.5 \%$. Two of six strains i.e. 106 and 106 had the ability to grow at $9.5 \% \mathrm{NaCl}$. These results are in the line with the findings obtained by Khalil (1999).

Indigenous Frankia isolates of Kafr El-Sheikh region surpassed the imported foreign reference Frankia strain and could be strongly recommended to be applied as inocula for inoculation shrubs and trees of Casuarina in different Egyptian salt-affected soils.

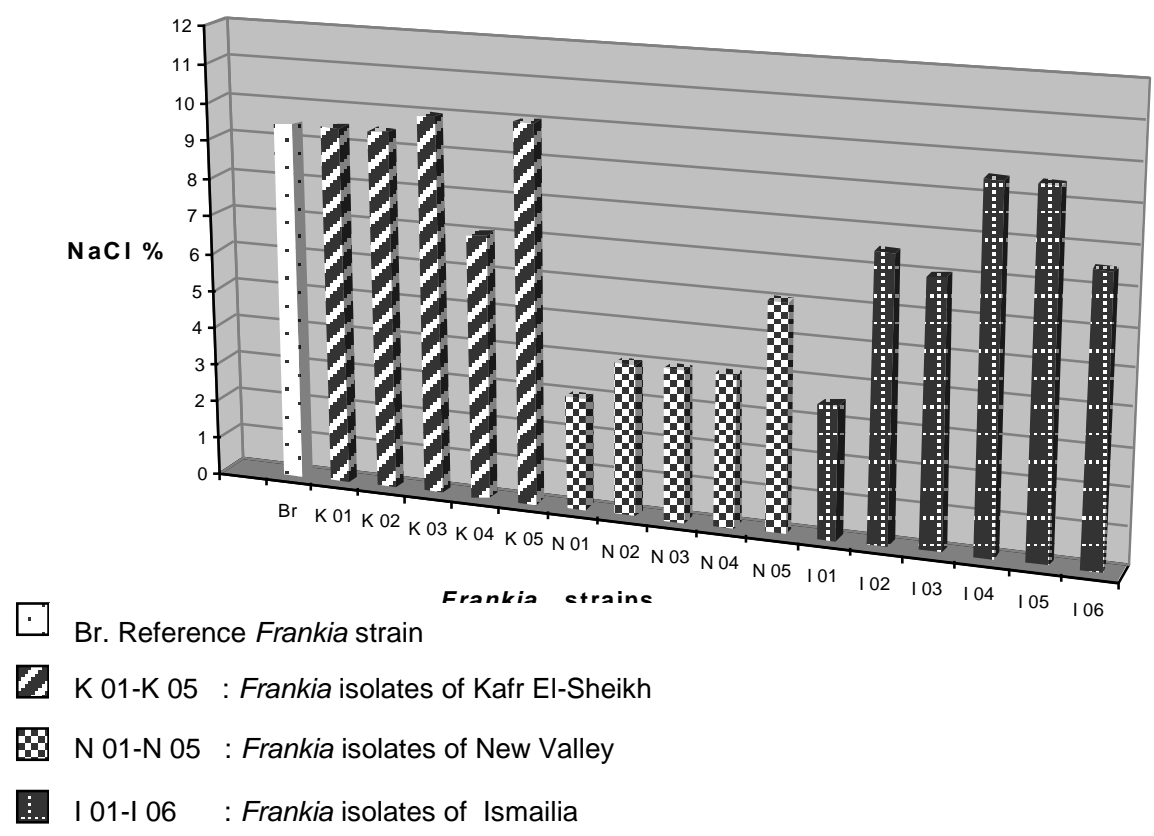

Fig. (3): Relation between Frankia isolates and $\mathrm{NaCl}$-salinity stresses.

\section{Utilization of various carbon sources:}

Table (5) demonstrates the response of using different carbon sources (6) by differed Frankia isolates and $\mathrm{Br}$ reference strain in BAP medium. Different types of $\mathrm{C}$-forms were utilized by the tested isolates in different degrees represented by their total Frankia colon counts units (CUF/ml). 
Data revealed that local isolates were more efficient than the foreign one. Generally, Kafr El-Sheikh isolates showed the highest utilization of the used carbon. The obtained results are in agreement with findings of Benson \& Schultz (1990) and Carrasco et al. (1995) who found that the utilization of carbon sources by Frankia strains was related to the genomic species that infect the members of the Elaeagnacease and Casuarinaceae, these strains grown on sugars and organic acids.

Generally the tested Frankia isolates differed in their carbon utilization from all different carbon sources. Most Fankia isolates from Kafr ElSheikh displayed greater response to different C-sources and surpassed the foreign $\mathrm{Br}$ strain.

Table (5): Utilization of several carbon sources by Frankia isolates.

\begin{tabular}{|c|c|c|c|c|c|c|}
\hline \multirow{2}{*}{$\begin{array}{l}\text { Frankia } \\
\text { isolates }\end{array}$} & \multicolumn{6}{|c|}{ Carbon sources } \\
\hline & $\begin{array}{c}\text { Na- } \\
\text { propionate }\end{array}$ & $\begin{array}{c}\text { Na- } \\
\text { pyruvate }\end{array}$ & $\begin{array}{c}\mathrm{Na}- \\
\text { acetate }\end{array}$ & Sucrose & Glucose & Mannitol \\
\hline & \multicolumn{6}{|c|}{ Frankia colony count units (CFU/ml) } \\
\hline $\mathrm{Br}$ & $3.8 \times 10^{3}$ & $3.9 \times 10^{3}$ & $2.4 \times 10^{3}$ & $2.3 \times 10^{3}$ & $5.9 \times 10^{4}$ & $>30$ \\
\hline K 01 & $7.1 \times 10^{4}$ & $3.6 \times 10^{4}$ & $7.0 \times 10^{4}$ & $5.9 \times 10^{6}$ & $5.1 \times 10^{6}$ & $3.7 \times 10^{6}$ \\
\hline $\mathrm{K} 02$ & $8.4 \times 10^{6}$ & $4.2 \times 10^{4}$ & $1.7 \times 10^{5}$ & $6.0 \times 10^{6}$ & $1.6 \times 10^{8}$ & $1.1 \times 10^{8}$ \\
\hline K 03 & $1.9 \times 10^{4}$ & $1.6 \times 10^{7}$ & $4.1 \times 10^{4}$ & $5.7 \times 10^{3}$ & $1.7 \times 10^{7}$ & $9.0 \times 10^{4}$ \\
\hline $\mathrm{K} 04$ & $1.5 \times 10^{5}$ & $1.8 \times 10^{4}$ & $4.9 \times 10^{4}$ & $3.1 \times 10^{4}$ & $1.3 \times 10^{6}$ & $2.5 \times 10^{4}$ \\
\hline K 05 & $1.9 \times 10^{4}$ & $5.0 \times 10^{4}$ & $4.8 \times 10^{4}$ & $1.2 \times 10^{6}$ & $9.0 \times 10^{5}$ & $<30$ \\
\hline N 01 & $2.7 \times 10^{2}$ & $6.1 \times 10^{3}$ & $<30$ & $87.5 \times 10^{1}$ & $1.0 \times 10^{1}$ & $<30$ \\
\hline $\mathrm{N} 02$ & $1.4 \times 10^{3}$ & $5.4 \times 10^{3}$ & $1.3 \times 10^{3}$ & $4.0 \times 10^{4}$ & $2.8 \times 10^{3}$ & $2.0 \times 10^{4}$ \\
\hline $\mathrm{N} 03$ & $3.2 \times 10^{1}$ & $3.6 \times 10^{5}$ & $<30$ & $6.2 \times 10^{4}$ & $3.3 \times 10^{2}$ & $4.4 \times 10^{3}$ \\
\hline $\mathrm{N} 04$ & $<30$ & $2.2 \times 10^{4}$ & $<30$ & $4.2 \times 10^{3}$ & $<30$ & $8.4 \times 10^{2}$ \\
\hline $\mathrm{N} 05$ & $2.4 \times 10^{2}$ & $3.7 \times 10^{2}$ & $2.0 \times 10^{2}$ & $2.5 \times 10^{3}$ & $1.5 \times 10^{3}$ & $2.6 \times 10^{4}$ \\
\hline 101 & $3.5 \times 10^{1}$ & $4.5 \times 10^{3}$ & $1.6 \times 10^{3}$ & $1.5 \times 10^{4}$ & $1.3 \times 10^{3}$ & $8.5 \times 10^{3}$ \\
\hline 102 & $1.5 \times 10^{4}$ & $4.7 \times 10^{3}$ & $1.2 \times 10^{4}$ & $2.1 \times 10^{2}$ & $5.0 \times 10^{2}$ & $5.2 \times 10^{3}$ \\
\hline 103 & $9.6 \times 10^{1}$ & $1.0 \times 10^{5}$ & $3.2 \times 10^{2}$ & $8.9 \times 10^{2}$ & $7.2 \times 10^{2}$ & $5.2 \times 10^{3}$ \\
\hline 104 & $8.5 \times 10^{2}$ & $9.7 \times 10^{3}$ & $5.3 \times 10^{3}$ & $1.1 \times 10^{3}$ & $1.4 \times 10^{3}$ & $1.6 \times 10^{3}$ \\
\hline 105 & $6.5 \times 10^{4}$ & $4.1 \times 10^{3}$ & $1.2 \times 10^{3}$ & $8.6 \times 10^{3}$ & $3.2 \times 10^{3}$ & $1.3 \times 10^{3}$ \\
\hline 106 & $6.1 \times 10^{1}$ & $1.7 \times 10^{2}$ & $7.9 \times 10^{1}$ & $1.3 \times 10^{2}$ & $2.3 \times 10^{2}$ & $2.7 \times 10^{2}$ \\
\hline $\begin{array}{l}01-\mathrm{K} 05 \\
\text { O1-N05 } \\
1-106\end{array}$ & \multicolumn{6}{|c|}{$\begin{array}{l}\text { : The reference strain } \\
\text { : Frankia isolates of Kafr El-Sheikh } \\
\text { : Frankia isolates of New Valley } \\
\text { : Frankia isolates of Ismailia }\end{array}$} \\
\hline
\end{tabular}

\section{Differentiation between Frankia isolates using DNA analysis:}

To differentiate between the isolated Frankia as well as the reference $\mathrm{Br}$ strain, the DAN plasmid analysis was carried out using the method of alkaline lysis with some modification. This method is able to isolate high molecular weight plasmids of Frankia (Rodriguez \& Tait, 1983). Harbor plasmid DNA as part of the genome could be used to differentiate between different Frankia isolates on genetic bases. The DNA plasmid patterns of Frankia isolates and the reference $(\mathrm{Br})$ strain which had different molecular weights are present in Fig. (4). Reference strain $\mathrm{Br}$ showed three high molecular weight plasmids (Lane 17). No small size plasmids were found in 
any of the tested isolates. Plasmids number of the tested Frankia isolates ranged from one to three plasmids per isolate. The Frankia isolates of Kafr El-Sheikh yielded one to three plasmid bands upon gel electrophoresis; one band was found in K 02 isolate (lane 2); three bands found in K 01 (lane 1) and two bounds in each of $\mathrm{K} 03 ; \mathrm{K} 04$ and $\mathrm{K} 05$ (lanes 3, 4 and 5) respectively.

The Frankia isolated from New Valley harbored plasmids ranged from one to two plasmid bands. One band has been found in each of $\mathrm{N} 01, \mathrm{~N}$ 03 and N 05 (lanes 6, 8 and 10); two plasmid bands noted in N 04 (lane 9), but no plasmid bands found in $\mathrm{N} 02$ (lane 7).

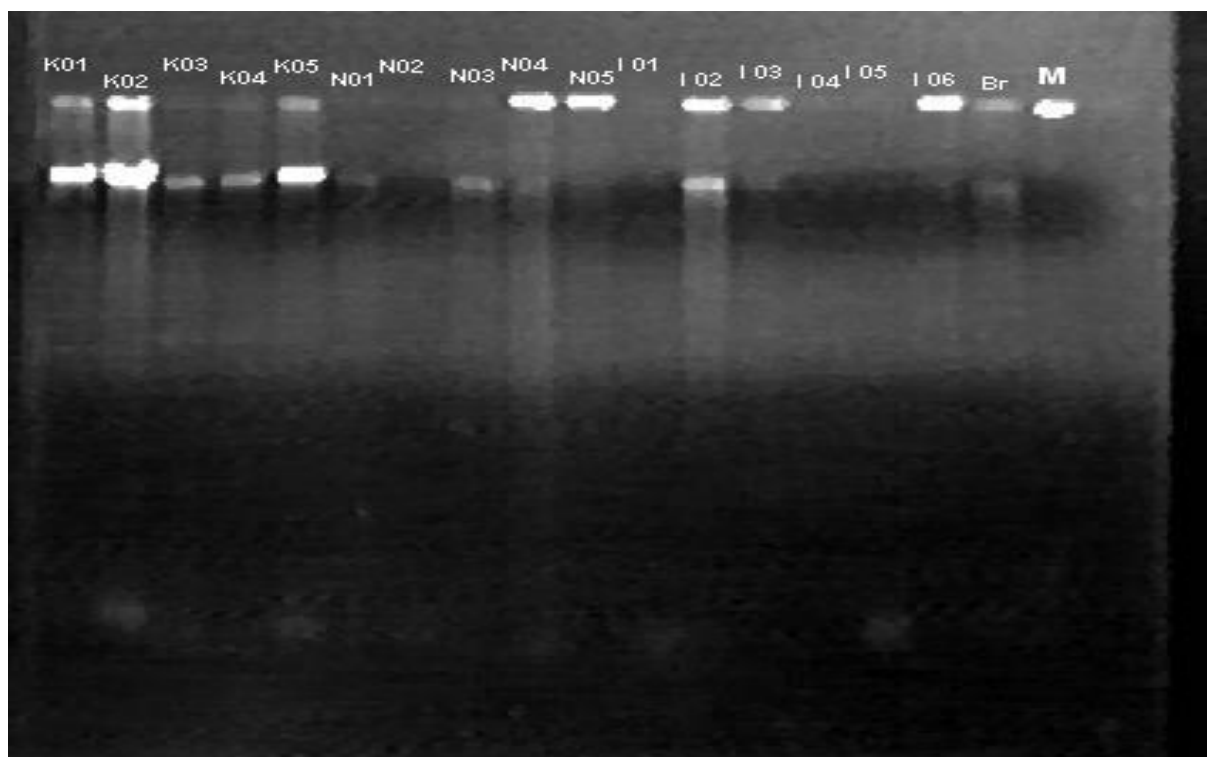

Fig. (4): The DNA plasmid patterns of isolated Frankia and their reference strain.

$\mathrm{Br} . \quad$ : The reference strain

K01-K05 : Frankia isolates of Kafr El-Sheikh

N01-N05 : Frankia isolates of New Valley

101-I06 : Frankia isolates of Ismailia

The Frankia isolates of Ismailia displayed that three of them I01, 104 and 105 (lanes 11, 14 and 15) have no plasmid bands, but isolate I 02 harbored two plasmids (lane 12), while isolates I 03 and I 06 (lanes 13 and 16) indicated only one plasmid band. In general, the highest number of plasmid bands was presented by Kafr El-Sheikh isolates and the lowest by Ismailia isolates. The different plasmid patterns among various isolates of Frankia are indication for their genetic diversity. The same results were reported among population of Frankia, where a wide variety of distinct plasmid profiles was found (Normand et al., 1983).

As illustrated in Fig. (5), total genomic DNA of the 16 Frankia isolates were isolated and migrated by electorphoresis in $0.7 \%$ agarose gel to 
differentiate between isolates. Results showed the differentiation between isolates in their migration through agarose gel electrophoresiss. These results represented that genetic diversity among Frankia isolates (An et al., 1985).

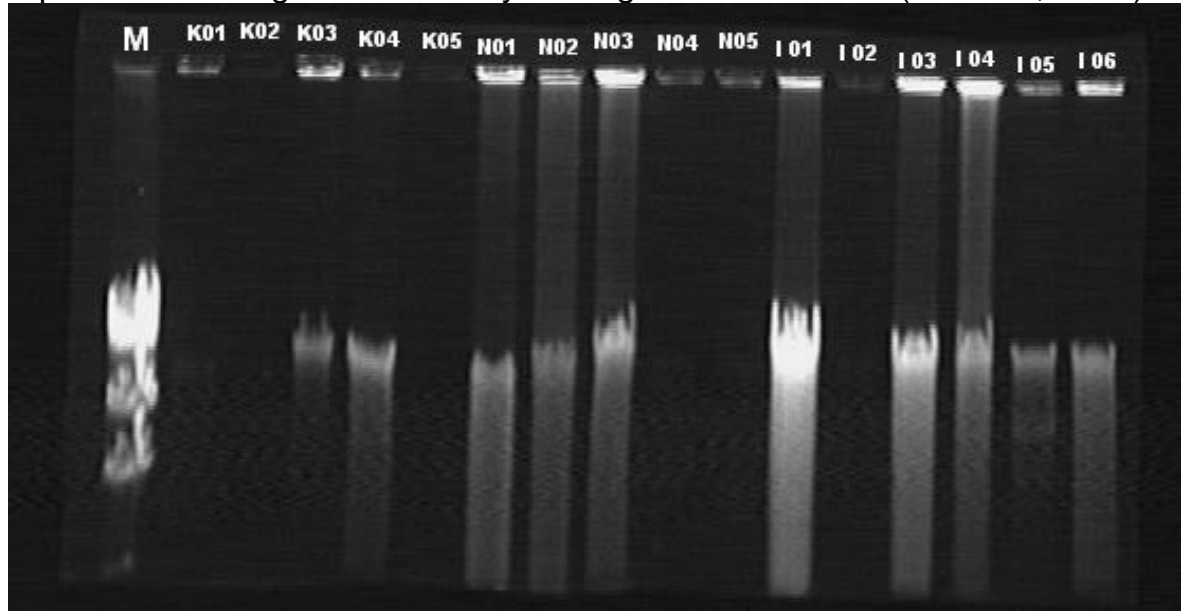

Fig. (5): Total genomic DAN from Frankia isolates and reference strain.

Br. : The reference strain

K01-K05 : Frankia isolates of Kafr El-Sheikh

N01-N05 : Frankia isolates of New Valley

I01-I06 : Frankia isolates of Ismailia

The characterization of Frankia isolates at the DNA level has revealed the existence of a large diversity (Rouvier et al., 1996) using RFLP of their DNA.

According to the different identification parameters which used to differentiate between the various Frankia isolates i.e. application of certain concentrations of different antibiotics; $\mathrm{NaCl}$ concentrations; types and utilization of different $\mathrm{C}$-sources as well as the genetic differentiation by plasmid DNA analysis; no similarity was recorded between the various tested Frankia isolates except the two isolates number $\mathrm{N} 01$ and $\mathrm{N} 03$ that were completely identical in all parameters.

Table (6) summares the obtained above mentioned results. So, it could be concluded that, the obtained Frankia isolates (15) are belonging to Frankia Casuarina strains.

Response of Casuarina seedlings to nodulation and growth:

Nodulation and vegetative growth of Casuarina glauca seedlings upon inoculation with local and $\mathrm{Br}$ foreign Frankia isolates were carried out under green-house conditions. Data listed in Table (7) revealed that no nodules were formed on Casuarina seedlings of the control treatment, i.e. sterilized growth medium and seeds. Nodules number ranged from 11 (I 03) to 18 (I 04) per seedling due to inoculation with Frankia isolates.

Most of local Frankia isolates induced nodulation and surpassed the foreign reference $\mathrm{Br}$ stain (12 nodules). Figs. (7 and 8 ) represent a nodulated Casuarina roots. 
The nodule dry weights ranged from 140 for ( $\mathrm{K} 05$ and $\mathrm{N} 04$ ) isolates and $820 \mathrm{mg} / \mathrm{seedling}$ with I 04 isolate. Also, the majority local Frankia isolates were significantly overcame the $\mathrm{Br}$ reference strain in nodule dry weights.

Table (6): Schematic diagram showing the summarized behavior of various tested Frankia isolates towards the tested parameters.

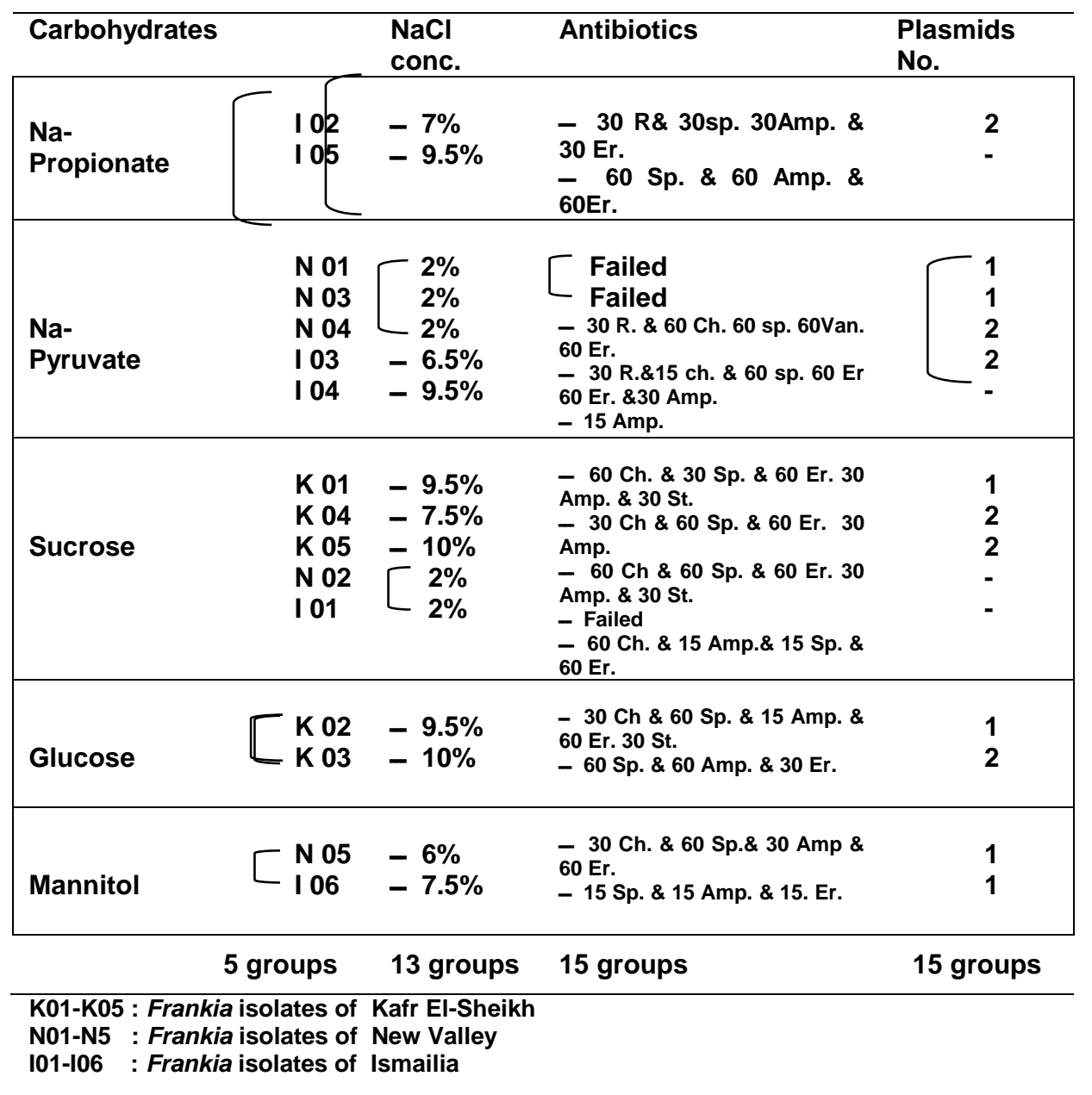

Most of Frankia isolates produced nodule numbers and nodule dry weights overmatched that obtained with $\mathrm{Br}$ reference strain being the highest with the strain I 04. These findings could be attributed to the high efficiency of active local Frankia isolates, which have more adaptation to Egyptian ecological conditions than the foreign $\mathrm{Br}$ strain. These obtained results were in line with those reported by Masuk \& Makoni (1995) and Zayed (2000) who 
found that inoculation with Frankia sp. increased nodules number and their dry weights.

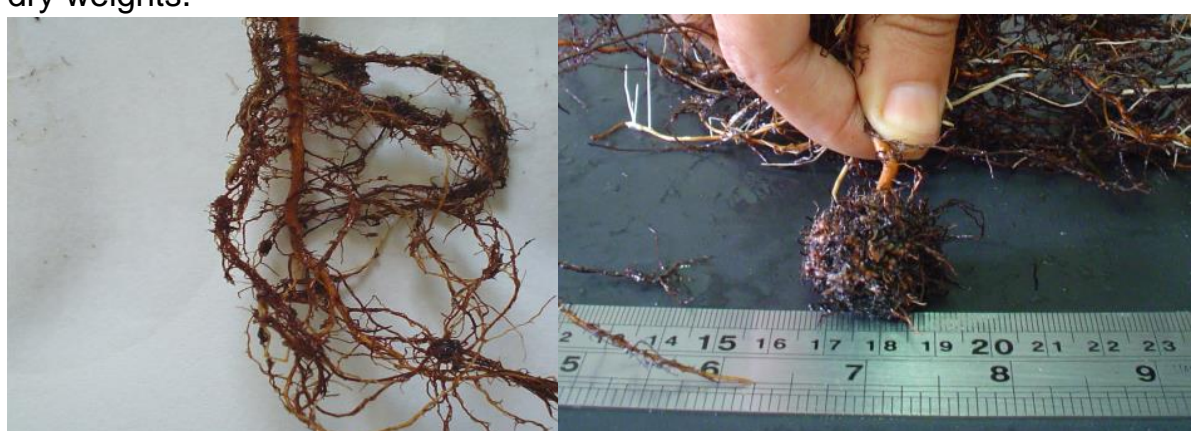

Fig. (7): Represent a nodulated Fig. (8): Micrograh of nodule formed Casuarina roots. on Casuarina roots by $\mathrm{K} 01$ isolate.

From Table (7) it could be concluded that inoculation with local Frankia isolates increased nodule numbers and their dry weights. Also, inoculation enhanced lengths and root dry weights, stem lengths and increased their branches numbers. Generally, Frankia isolate I 04 recorded the highest assessed nodulation and the vegetative growth parameters.

Table (7): Effect of inoculation with Frankia isolates and $\mathrm{Br}$ reference strain on the nodulation of Casuarina glauca and its vegetative parameters.

\begin{tabular}{|c|c|c|c|c|c|c|c|}
\hline Rarameters & $\begin{array}{c}\text { Nodules } \\
\text { (No/ } \\
\text { seedling) }\end{array}$ & $\begin{array}{c}\text { Nodules } \\
\text { D.Wt. (mg/ }\end{array}$ & $\begin{array}{c}\text { Root } \\
\text { length } \\
\text { seedling) }\end{array}$ & $\begin{array}{c}\text { Root } \\
\text { (cm) }\end{array}$ & $\begin{array}{c}\text { Shoots } \\
\text { seedling) } \\
\text { s.wt. } \\
\text { Treatments } \\
\text { (g/seedling) }\end{array}$ & $\begin{array}{c}\text { Branches } \\
\text { (no/ } \\
\text { seedling) }\end{array}$ & $\begin{array}{c}\text { Stem } \\
\text { length } \\
\text { (cm) }\end{array}$ \\
\hline Control & 0 & 0 & 10.33 & 0.20 & 0.96 & 4.0 & 15.33 \\
\hline Br & 12 & 180 & 20.33 & 0.57 & 3.58 & 2.7 & 24.33 \\
\hline K 01 & 17 & 620 & 20.00 & 1.37 & 4.57 & 2.7 & 25.00 \\
K 02 & 15 & 250 & 16.67 & 0.73 & 2.35 & 1.7 & 32.67 \\
K 03 & 13 & 440 & 16.67 & 0.92 & 3.55 & 3.3 & 27.67 \\
K 04 & 14 & 590 & 16.00 & 0.88 & 2.56 & 4.3 & 24.33 \\
K 05 & 13 & 140 & 165.00 & 0.69 & 3.55 & 4.0 & 31.67 \\
\hline N 01 & 13 & 560 & 13.67 & 0.33 & 1.89 & 4.7 & 24.0 \\
N 02 & 14 & 420 & 20.00 & 0.53 & 1.86 & 2.0 & 22.33 \\
N 03 & 14 & 380 & 17.33 & 0.61 & 1.19 & 1.7 & 21.67 \\
N 04 & 14 & 140 & 18.00 & 0.51 & 1.27 & 1.0 & 23.33 \\
N 05 & 13 & 210 & 15.33 & 0.70 & 2.41 & 4.0 & 25.67 \\
\hline I 01 & 13 & 330 & 13.00 & 0.82 & 2.30 & 2.0 & 29.00 \\
I 02 & 13 & 270 & 14.33 & 0.57 & 2.81 & 5.0 & 17.00 \\
I 03 & 11 & 260 & 18.33 & 0.94 & 2.50 & 4.0 & 32.00 \\
I 04 & 18 & 820 & 25.00 & 1.30 & 5.53 & 6.3 & 36.00 \\
I 05 & 11 & 250 & 17.33 & 0.56 & 3.36 & 5.0 & 33.33 \\
I 06 & 14 & 440 & 12.67 & 0.69 & 2.53 & 5.7 & 24.33 \\
\hline
\end{tabular}

Each value is a mean of 3 replicates

$\mathrm{Br}$ : : The reference strain

K01-K05 : Frankia isolates of Kafr El-Sheikh

N01-N05 : Frankia isolates of New Valley

I01-I06 : Frankia isolates of Ismailia 


\section{Efficacy of Casuarina seedlings to symbiotic $\mathrm{N}_{2}$-fixation:}

Performance symbiotic $\mathrm{N}_{2}$-fixation trials of local isolated Frankia from different ecological regions in comparison with the foreign Frankia reference strain from Chile (ORS020608) were judged by the N-content of roots and shoots as well as $\mathrm{N}$-uptake (mg/seedling) of Casuarina seedlings cultivated in the studied soils. Data listed in Table (8) showed that these N-parameters of non-inoculated Casuarina seedlings with Frankia were recorded the lowest values in both calcareous and sandy soils (control) in comparison with the inoculated seedlings. Efficacy of Casuarina seedlings to $\mathrm{N}_{2}$-fixation was significantly increased upon inoculation with Frankia strains. As shown in Table (8) N-parameters of inoculated Casuarina seedlings with foreign Frankia strain were significantly increased in comparison with the control.

In addition, inoculation of Casuarina seedlings with indigenous isolated Frankia led to highly significant increasing in $\mathrm{N}$-parameters in comparison with the corresponding values of the $(\mathrm{Br})$ reference Frankia strain.

This means that local Frankia isolates were significantly surpassed the foreign Frankia strain in $\mathrm{N}_{2}$-fixation efficiency. Inoculation of cultivated Casuarina seedlings with Frankia isolates of Ismailia region (I.S 146.6 mmoles $\mathrm{L}^{-1}$ ) gave significantly the highest $\mathrm{N}$-values in Mariout calcareous soils (I.S7.25 mmoles $\mathrm{L}^{-1}, \mathrm{CaCO}_{3} 30.2 \%$ and clay content (64\%). Grand mean values of $\mathrm{N}$-content of roots; shoots and $\mathrm{N}$-uptake were $2.73 \%, 1.84 \%$ and $1376.4 \mathrm{mg} /$ seedling respectively.

Isolate 104 displayed the greatest values. However these isolates recorded the lowest values in El-Nobaria sandy soils (I.S 23.65 mmoles $\mathrm{L}^{-1}$, $\mathrm{CaCO}_{3} 1.4 \%$ and sand content $92.5 \%$ ), which were $0.94 \%, 0.95 \%$ and $461.46 \mathrm{mg} / \mathrm{seedling}$. It could be concluded that, $\mathrm{N}_{2}$-fixation capability of Frankia isolates of Ismailia in calcareous soils was more higher than those in sandy soils. Inoculated Casuarina seedlings with Frankia isolates of Kafr ElSheikh (I.S. 178.85 mmoles L-1) cultivated in Mariout calcareous soils gave the lowest significant values which were $1.63 \%, 1.14 \%$ and 403.9 $\mathrm{mg} / \mathrm{seedling}$ respectively. These isolates registered the highest values in ElNobaria sandy soils, which were $2.06 \%, 1.99 \%$ and $1222.75 \mathrm{mg} / \mathrm{seedling}$ respectively. K01 isolate represented the greatest values.

$\mathrm{N}_{2}$-fixation by Frankia isolates of Kafr El-Sheikh in sandy soils was more efficient than in calcareous soils. Inoculation of Casuarina seedling with Frankia isolates of New Valley (I.S. 13.05 mmoles L $^{-1}$ ) displayed moderately values.

This observations could be ascribed to the adaptation of the studied isolates to the areas from which they were isolated (Table 1 and 2), which are in harmony with those obtained by Zhang et al. (1990) and Khalil (1999) who reported that different Casuarina genotypes inoculated with pure Frankia strains showed significant $\mathrm{N}_{2}$-fixation and $\mathrm{N}$-uptake per plant.

From the above mentioned investigations it is clear that the most of local Frankia isolates specially Kafr El-Sheikh and Ismailia isolates could be recommended as highly efficient and specific biofertilizer for Casuarina 
inoculation under different drought conditions in Egypt for rough agricultural, ecological stabilization.

Table (8): N-content of roots, shoots and N-uptake of Casuarina glauca seedlings in studied soils as affected with Frankia isolates.

\begin{tabular}{|c|c|c|c|c|c|c|}
\hline \multirow{3}{*}{ Treatments } & \multicolumn{3}{|c|}{ Calcareous soil } & \multicolumn{3}{|c|}{ Sandy soil } \\
\hline & \multicolumn{2}{|c|}{ N-content (\%) } & \multirow{2}{*}{\begin{tabular}{|c|} 
N-uptake \\
(mg/seedling)
\end{tabular}} & \multicolumn{2}{|c|}{ N-content (\%) } & \multirow{2}{*}{$\begin{array}{c}\mathrm{N} \text {-uptake } \\
\text { (mg/seedling) }\end{array}$} \\
\hline & Roots & Shoots & & Roots & Shoots & \\
\hline Cont. & 0.20 & 0.37 & 45.26 & 0.45 & 0.40 & 39.98 \\
\hline $\mathrm{Br}$ & 1.14 & 1.45 & 258.22 & 1.50 & 1.50 & 612.90 \\
\hline K01 & 2.80 & 2.23 & 695.65 & 3.55 & 3.35 & 2782.77 \\
\hline K02 & 1.50 & 0.90 & 320.64 & 0.76 & 1.40 & 555.98 \\
\hline K03 & 0.15 & 0.32 & 93.72 & 1.63 & 1.40 & 1055.65 \\
\hline K04 & 2.05 & 0.30 & 575.75 & 1.90 & 1.70 & 639.61 \\
\hline K05 & 1.65 & 1.95 & 333.72 & 2.45 & 2.10 & 1079.72 \\
\hline Grand mean K & 1.63 & 1.14 & 403.9 & 2.06 & 1.99 & 1222.75 \\
\hline $\mathrm{N} 01$ & 1.38 & 1.65 & 310.88 & 2.05 & 2.00 & 804.61 \\
\hline N02 & 1.42 & 1.00 & 734.95 & 2.45 & 1.65 & 1276.33 \\
\hline N03 & 2.37 & 0.90 & 710.57 & 1.75 & 1.78 & 883.60 \\
\hline N04 & 2.45 & 2.55 & 1383.3 & 1.05 & 1.78 & 557.60 \\
\hline N05 & 2.90 & 2.15 & 575.70 & 1.80 & 2.30 & 1306.26 \\
\hline Grand mean N & 2.10 & 1.65 & 743.1 & 1.82 & 1.90 & 965.68 \\
\hline 101 & 2.70 & 1.05 & 1035.00 & 0.85 & 0.64 & 371.46 \\
\hline 102 & 2.30 & 1.75 & 963.90 & 0.79 & 0.85 & 463.63 \\
\hline 103 & 3.55 & 3.35 & 1538.70 & 1.40 & 1.10 & 683.43 \\
\hline 104 & 3.70 & 2.55 & 3031.25 & 0.55 & 1.25 & 352.13 \\
\hline 105 & 2.25 & 1.55 & 1113.40 & 0.85 & 0.95 & 525.01 \\
\hline 106 & 1.90 & 0.80 & 576.18 & 1.20 & 0.85 & 373.10 \\
\hline Grand mean I & 2.73 & 1.84 & 1376.4 & 0.94 & 0.95 & 461.46 \\
\hline Total grand mean & 2.16 & 1.54 & 841.13 & 1.60 & 1.61 & 883.29 \\
\hline $\begin{array}{ll}\text { BR } & \text { : The r } \\
\text { K01-K05 } & : \text { Fran } \\
\text { N01-N-05 } & : \text { Fran } \\
\text { I01-I06 } & : \text { Fran }\end{array}$ & erenc & rain & $\begin{array}{l}\text { I-Sheikh } \\
\text { Valley }\end{array}$ & & & \\
\hline
\end{tabular}

\section{REFERENCES}

Allen, O.N. (1953). Experiments in Soil Bacteriology. Ins. (ed.). Burges Publ. USA.

An, C.S.; W.S. Riggsby and B.C. Mullin (1985). Restriction pattern analysis of genomic DNA of Frankia isolates. Plant and Soil, 87: 43-48.

Baker, D. and D. O'keefe (1984). A modified sucrose fractionation procedure for the isolation of Frankia from actinorhizal roots nodules and soil samples. Plant and Soil, 78: 23-28.

Becking, J.H. (1981). The genus Frankia. Pages 1991-2003. In M.P. Starr; H. Stolp; H.G. Trueper; A. Balows and H.G. Schlegel (eds.): The Prokaryotes: A Handbook on Habitats, Isolation and Identification of Bacteria. Springer-Verlag, Berlin.

Benson, D.R. (1982). Isolation of Frankia strains from alder actinorhizal nodules. Appl. Environ. Microbiol., 44: 461-465. 
Benson, D.R. and N.A. Schultz (1990). Physiology and biochemistry of Frankia in culture. Pages 107-127. In C.R. Schwintzer \&J.D. Tjepkema (eds.): The Biology of Frankia and Actinorhizal Plants. Academic Press, Inc., New York.

Benson, D.R. and W.B. Silvester (1993). Biology of Frankia strains, actinomycete symbionts of actinorhizal plants. Microbiol. Rev., 57(2): 297-319.

Burt, L. (2004). Soil Survey Laboratory Methods Manual. USDA-NRCS, Lincoln, Nebraska.

Callaham, D.; P.Del-Tredici and J.G. Torrey (1978). Isolation and cultivation in vitro of the actinomycete causing root nodulation in Comptonia. Science, 1991: 899-902.

Carrasco, A.; J.R. Salyards and A.M. Berry (1995). Studies on two Frankia strains isolated from Trevoa trinervis Miers. Plant and Soil, 171: 359363.

Carter, M.R. (ed.) (1993). Soil Sampling and Methods of Analysis. Canadian Society of Soil Science. Lewis Publishers, Boca Raton, London, Tokyo.

Dawson, J.O. (1990). Interactions among actinorhizal and associated plant species. Pages 229-316. In C.R. Schwintzer and J.D. Tjepkema (eds.): The Biology of Frankia and Actinorhizal plants. Academic Press Inc., New York.

Diem, H.G. and Y.D. Dommergues (1984). In vitro production of specialized reproductive torulose hyphae by Frankia strains ORS021001 isolated from Casuarina junghuhniana. In: Current research on Frankia and Actinorhizal plants. International Symposium, Montmorency Forest, Aug. 5-9th Laval Univ.

Diem, H.G. and Y.R. Dommergues (1983). The isolation of Frankia from nodules of Casuarina equisetifolia. Can. J. Microbiol., 61(11): 28222825.

Diem, H.G. and Y.R. Dommergues (1990a). Isolation, characterization and cultivation of Frankia. Pages 227-254. In C.R. Schwintzer and J.D. Tjepkema (eds.): The Biology of Frankia and Actinorhizal Plants. Academic Press, Inc. New York.

Diem, H.G. and Y.R. Dommergues (1990b). Current and potential uses and management of Casuarina in the tropics and subtropics. Pages 317342. In C.R. Schwintzer and J.D. Tjepkema (eds.): The Biology of Frankia and Actinorhizal Plants. Academic Press, Inc., New York.

Difco (1976). Difco Manual of Dehydrated Culture Media and Reagents of Microbiological and Clinical Laboratory Procedures. (10 th Ed.). Difco Lab. Inc. Detroit, L., Michigan, USA.

El-Lakany, M.H. (1983a). Breeding and improving of Casuarina: a promising multipurpose tree for arid regions of Egypt. Pages 58-65. In S.J. Midgley, J.W. Turnbull and R.D. Johnston (eds.): Casuarina Ecology Management and Utilization. CSIRO, Melbourne, Australia. 
El-Lakany, M.H. (1983b). A review of breeding drought resistant Casuarina for shelterbelt establishment in arid regions with special reference to Egypt. For. Ecol. Manage, 8: 129-137.

El-Lakany, M.H. (1985). Biological effect of shelterbelts and windbreaks in arid regions. Int. Brise-Vent, IDRC-MR 117 : 104-110.

El-Lakany, M.H. (1986). Nitrogen fixing trees with special reference to Casuarina. Pages 373-378. In A.M. Abdel-Hafez; M.E. El-Haddad and M.N. Magdoub (eds.): Proceeding of the Second Conference of the African Association for Biological Nitrogen Fixation. Cairo MIRCEN, Egypt.

Evans, H.J.; B. Koch and R. Klucas (1972). Preparation of nitrogenase from nodules and separation into components. Meth. Enzymol., 24: 470476.

Fontaine, M.F.; P.H.Young and J.G. Torrey (1986). Effect of long term preservation of Frankia strains on infective, effective and in vitro nitrogenase activity. Appl. Environ. Microbiol., 51: 964-968.

Fontaine, M.F.; S.A. Lancelle and J.G. Torrey (1984). Initiation and ontogeny of vesicles in cultured Frankia sp. strain HFPAr 13. J. Bacteriol., 160: 921-927.

Franche, C.; L. Laplaze; E. Duhoux and E. Bogusz (1998). Actinorhizal symbiosis: Recent advances in plant molecular and genetic transformation studies. Critical Reviews in Plant Sciences, 17(1): 1-28.

Gauthier, D.; H.G. Diem and Y.R. Dommergues (1984). Tropical and subtropical actinorhizal plants. Presqui Agropecu Bras, 19 s/n: 119136.

Girgis, M.G.Z.; Y.Z. Ishac; M. El-Haddad; E.A. Salah; H.G. Diem and Y.R. Dommergues (1990). First report on isolation and culture of effective Casuarina-compatible strains of Frankia from Egypt. Pages 156-164. In M.H. El-Lakany; J.W. Turnbull and J.L. Breweaker (eds.); Proceedings of the Second International Casuarina Workshop. American University, Cairo, Egypt.

Huss-Danell, K. (1990). The physiology of actinorhizal nodules. Pages 129156. In C.R. Schwintzer \& J.D. Tjepkema (eds.): The Biology of Frankia and Actinorhizal Plants. Academic Press, Inc., New York.

Johnson, L.A.S. and K.L. Wilson (1989). Casuarinaceae: a synopsis. Pages 167-188. In P.R. Carne and S. Blackmore (eds.): Evaluation, Systematics and Fossil History of the Hamamelidae, Special Volume No. 40 B. Clarendon Press, Oxford.

Khalil, M.K. Hala (1999). Response of some Casuarina sp. to Frankia infection in different culture conditions. Ph.D. Thesis, Zagazig Univ., Egypt.

Klute, A. (ed.) (1986). Method of Soil Analysis. Part 1, (2nd Ed.): Physical and Mineralogical Methods. ASA, Inc., SSSA, Inc. Publisher, Madison, Wisconsin USA.

Lalonde, M. and H.E. Calvert (1979). Production of Frankia hyphae and spores as an infective inoculant for Alnus species. Pages 95-110. In 
J.C. Gordon et al. (eds.): Symbiotic Nitrogen Fixation in the Management of Temperate Forests. For. Res. Lab., Oregon State Univ., Corvallis.

Lalonde, M.; H.E. Calvert and S. Pine (1981). Isolation and use of Frankia strains in actinorhizal formation. Pages 296-299. In A.H. Gihson and W.E. Newton (eds.): Current Perspectives in Nitrogen Fixation. Australian Academy of Sciences, Canberra, Australia.

Long, S.R. (1996). Rhizobium symbiosis: Nod factors in perspective. Plant Cell, 6: 1651-1668.

Louis, S.T.; S.C. Matthew; D.K. Glenn and R. Joel (1999). Antibiotic resistance patterns of Frankia strains. Canadian J. Bot., 77(9): 12571260.

Louw, H.A. and M. Webley (1959). The bacteriology of the root region of the oat plant grown under controlled pot culture conditions. J. Appl. Bacteriol., 22: 216-221.

Mariana, O.; S.Y. Mame; L. Laurent; S.I. Carole; S. Sergio; A. Florence; B. Didier and F. Claudine (2003). Actinorhizal nitrogen fixing nodules: Infection process, molecular biology and genomics. African Journal of Biotechnology, Vol. 2(12): 528-538.

Masuk, A.J. and J. Makoni (1995). Effect of Frankia, phosphate and soil type on nodulation and growth of Casuarina cunninghamiana Miq. in Zimbabwe. South African Forestry Journal, 172: 13-17.

Meesters, T.M.; S. Th. van Genesen and A.D.L. Akkermans (1985). Growth, acetylene reduction activity and localization of nitrogenase in relation to vesicle formation in Frankia strains Ccl. 17 and Cpl.2. Arch. Microbiol., 143: 137-142.

Muller, A.; P. Benoist; H.G. Diem and J. Schwencke (1991). Age-dependent changes in extracellular proteins, aminopeptidase and proteinase activities in Frankia isolate BR. J. Gen. Microbiol., 137: 2787-2796.

Mullin, B.C. and S.V. Dobritsa (1996). Molecular analysis of actinorhizal symbiotic systems: Progress to date. Plant Soil, 186: 9-20.

Normand, P.; P. Simonet; J.L. Butour; C. Rosenberg; A. Moiroud and M. Lalonde (1983). Plasmids in Frankia sp. J. Bacteriol., 155: 32-35.

Page, A.L. R.H. Miller and D.R. Keeney (eds) (1982). Methods of Soil Analysis. Part 2, (2 ${ }^{\text {nd }}$ Ed.): Chemical and Microbiological properties. ASA, Inc., SSSA, Inc. Publisher, Madison, Wisconsin USA.

Pawlowski, K. and T. Bisseling (1996). Rhizobial and actinorhizal symbiosis: What are the shared features? Plant Cell, 6: 1899-1913.

Rennie, R.J. (1981). A single medium for isolation of acetylene-reducing (dintitrogen fixing) bacteria from soils. Can. J. Microbiol., 27: 8-14.

Rodriguez, R. and R.C. Tait (1983). Recombinant DNA Techniques: An Introduction. The Benjamin/Cummings Publishing Company, Inc., Menlopark, California, Reading, Massachusetts, London, Amesterdam, Dan Mills, Ontario, Sydney.

Rouiver, C.; Y. Prin; P. Reddell; P. Normand and P. Simonet (1996). Genetic inversity among Frankia strains nodulating members of the family Casuarinaceae in Australia revealed by PCR and restriction fragment 


\section{El-Kammah, M. A. et al.}

length polymorphism analysis with crushed root nodules. Appl. Environ. Microbiol., 62: 979-985.

Schultz, N.A. and D.R. Benson (1989). Developmental potential of Frankia vesicles. J. Bacteriol., 171: 6873-6877.

Selim, Sh. and J. Schwencke (1995). Simple and reproducible nodulation test for Casuarina-compatible Frankia strains: Inhibition of nodulation and plant performance by some cations. Arid Soil Res. Rehabit, 9: 25-37.

Szabo, I. (1974). Microbial Communities in a Forest-Rendzina Ecosystem. Akademia Kiada, Budapest.

Zayed, M.S. Mona (2000). Studies on Frankia in some Egyptian soils. M.Sc. Thesis, Ain Shams University.

Zhang, Z.; F. Zapata and G.D. Bowen (1990). Infectiveness and effectiveness of two Frankia strains on genotypes of Casuarina sp. 149-155 ISBN 977-424-245-9 IAEA Seibersdorf Laboratory. Austria.

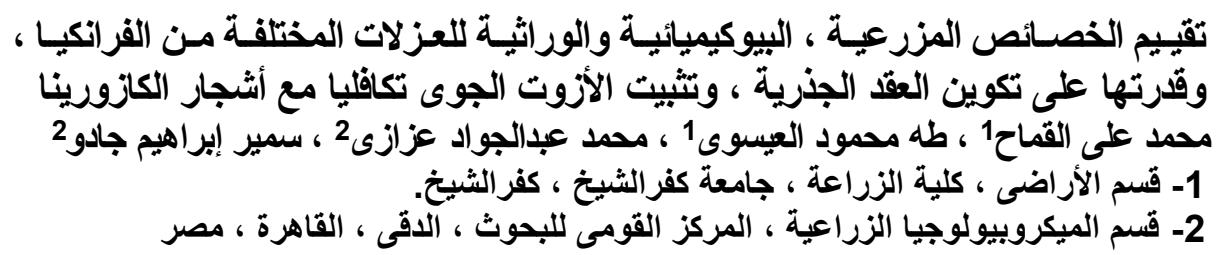

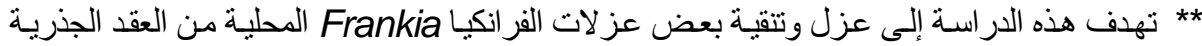

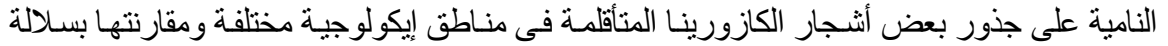

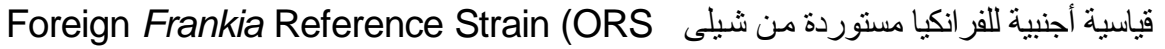
.020608)

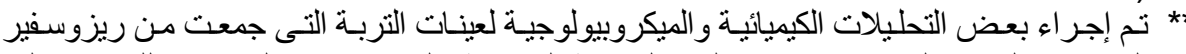

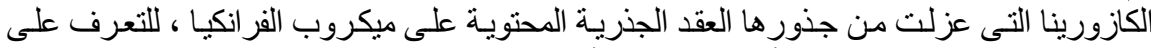

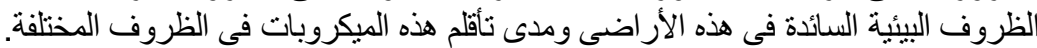

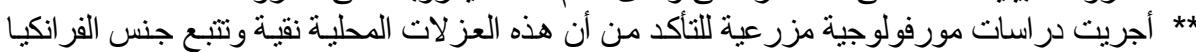

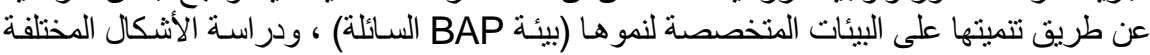

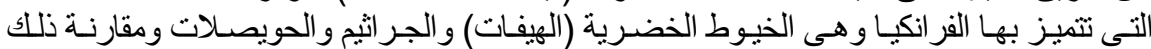

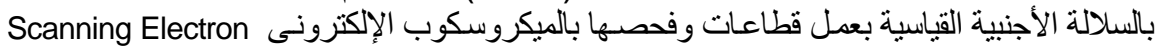
Microscopy (10000X)

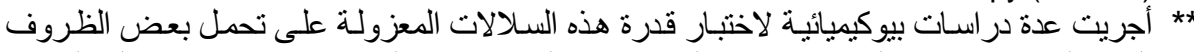

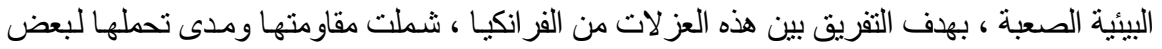

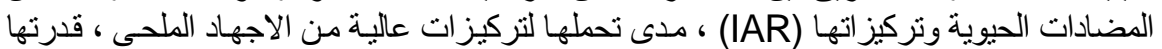

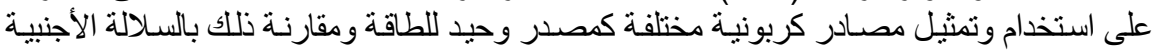

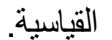

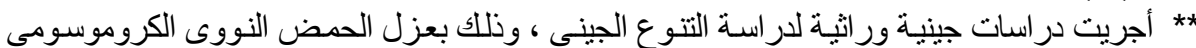

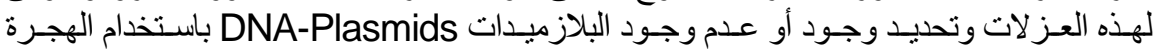

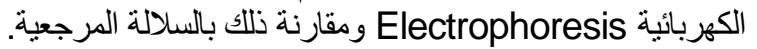

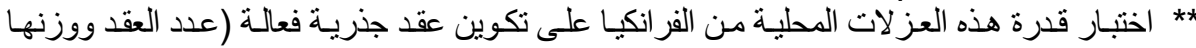

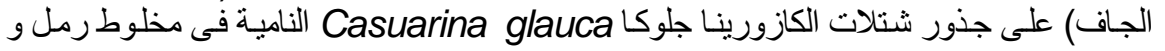




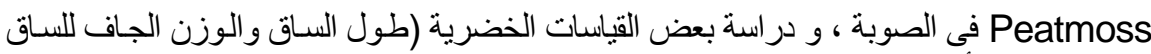
و والجذر و عدد الأفرع) ومقارنتها بالسلالة القياسية.

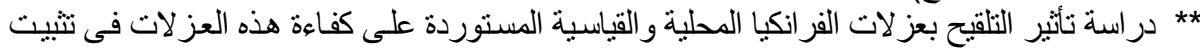

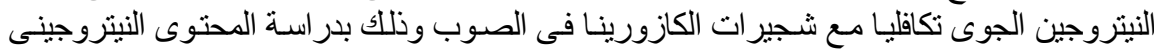

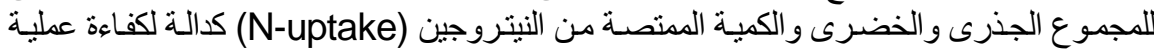

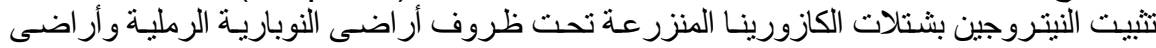

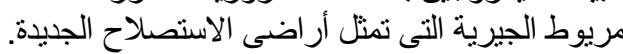

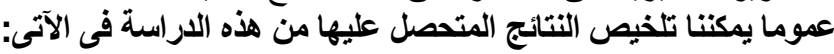

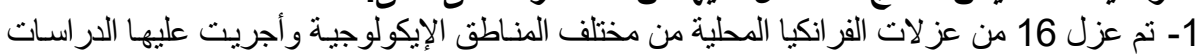

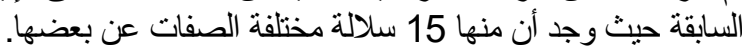

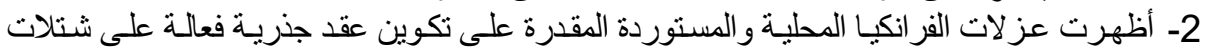

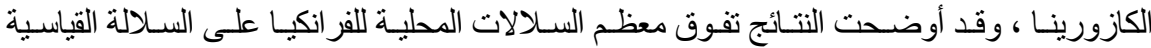

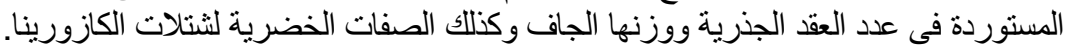

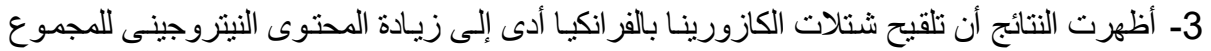

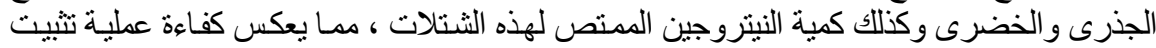

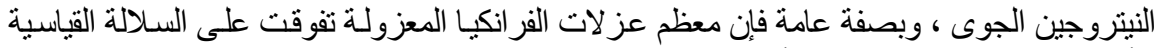

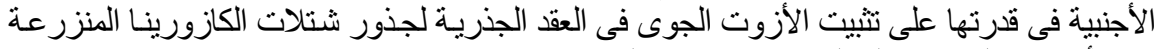

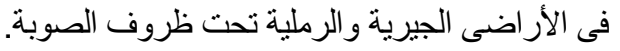

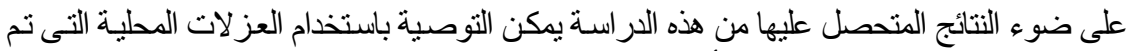

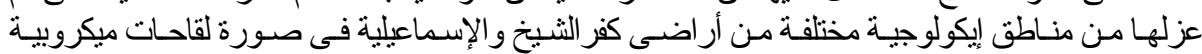

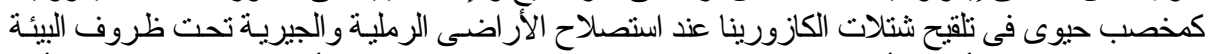

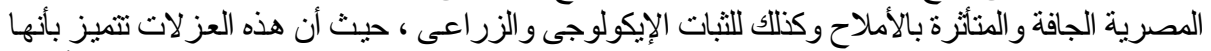

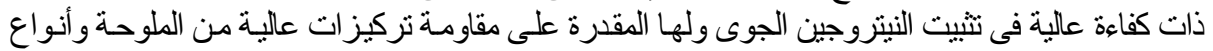

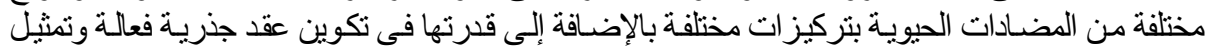
و واستخدام مصادر كربونية مختلفة كمصر وحيد للطاقة. 